\title{
Kajian Simbol-Simbol Etnisitas dalam Kampanye, Komunikasi Politik dan Pergeserannya pada Pemilukada Kabupaten Poso
}

\author{
Ilyas \\ Program Studi Ilmu Komunikasi Fakultas Ilmu Sosial dan Ilmu Politik \\ Universitas Tadulako \\ Jl. Soekarno Hatta Km.9 Kampus Bumi Kaktus, Kelurahan Tondo, Palu Kode Pos 94118 \\ HP: 081342654249, e-mail: balaula_lias@yahoo.com
}

\begin{abstract}
This research was based on the issue of the use of ethnicity and religion in politics that happens in the election of regional head in a conflict prone area. This happens mostly in an area with diverse ethnicities and religions, for instance Poso district. Besides that, Poso has long story of violent conflict caused by ethnicity and religion, and this makes it even more interesting to know how ethnicity is constructed in the election of regional head recent context. The method used was qualitative research with symbolic interaction approach, where social life is essentially a human interaction with the use of symbols. The result of the research in the 2010 election of regional head showed that the construction of ethnicity and religious symbols by potential candidate of District's Head and its vice has emphasized on local candidates, use of traditional customs, ethnicity's organization, local language, and symbols of religious organization. But it's unfortunate that those issues have been undermined by security and legal order that become very interesting for the voters. The image of conflict, which has traumatized society of Poso, has swept away the ethnic issues, because they realized the importance of living in peace and secure.
\end{abstract}

\begin{abstract}
Abstrak
Latar belakang penelitian ini adalah maraknya politisasi etnis dan agama pada pemilukada langsung yang diselenggarakan di berbagai daerah, yang seringkali bahkan menimbulkan konflik kekerasan. Situasi ini banyak ditemukan pada daerah yang memiliki heterogenitas etnik dan agama yang tinggi, seperti Kabupaten Poso. Selain itu Poso memiliki sejarah panjang konflik yang bernuansa etnis dan agama sehingga menarik untuk mengetahui bagaimana etnisitas dikonstruksi pada kampanye pemilukada. Metode penelitian yang digunakan adalah kualitatif dengan pendekatan interaksi simbolik, di mana kehidupan sosial pada dasarnya adalah interaksi manusia dengan menggunakan simbol-simbol. Pengumpulan data dilakukan dengan wawancara mendalam dan dokumentasi selama kampanye berlangsung. Hasil penelitian mengungkapkan bahwa pada pemilukada Kabupaten Poso tahun 2010, konstruksi simbol-simbol etnis dan agama yang dilakukan oleh para calon bupati dan wakil bupati diantaranya adalah menonjolkan isu putera daerah, penggunaan pakaian adat, penggunaan simbolsimbol organisasi paguyuban etnis, penggunaan bahasa daerah dan juga simbolisasi organisasi keagamaan. Hanya saja simbol-simbol tersebut kemudian kalah oleh isu keamanan dan ketertiban yang justru menjadi isu paling menarik simpati pemilih. Bayangan konflik yang begitu traumatik bagi masyarakat Poso menggeser isu-isu etnisitas tersebut, karena adanya kesadaran baru pentingnya hidup aman dan damai.
\end{abstract}

Kata kunci : konstruksi simbol, etnisitas dan kampanye pemilukada 


\section{Pendahuluan}

Pemilukada adalah salah satu bentuk pelaksanaan demokrasi yang bertujuan untuk menciptakan sebuah tatanan pemerintahan yang bersih, akuntabel, dan demokratis. Penerapan otonomi daerah dan demokratisasi politik telah berkonsekuensi pada beragam bentuk penyelenggaraan pemerintahan, salah satunya adalah dalam menentukan kepemimpinan lokal melalui pemilihan kepala daerah secara langsung. Sistem ini lalu berdampak pada upaya merebut simpati khalayak dalam usaha meningkatkan elektabilitas seseorang yang ingin berkontestasi pada pemilukada. Karenanya ruang-ruang pemanfaatan desain dan strategi komunikasi politik yang jitu dalam kontestasi menemukan penegasannya.

Pada masyarakat yang multietnik, dinamika komunikasi politik, khususnya pada masa kampanye memiliki tingkat kerumitan dalam menentukan isu dibandingkan pada daerah yang masyarakatnya relatif homogen. Alih-alih meraih simpati public seringkali malah kontraproduktif dengan tujuan yang ditargetkan bahkan menjadi konflik kekerasan. Hal tersebut dapat kita lihat pada kontestasi politik di tingkat lokal pada beberapa pemilukada propinsi, kabupaten, dan kota yang selalu menyita perhatian banyak pihak karena persaingan yang melibatkan simbol-simbol etnisitas baik agama, suku, putra daerah atau pendatang. Simbol-simbol tersebut kerap dijadikan isu politik dalam sosialisasi dan komunikasi politik para calon yang bersaing berebut jabatan politik seperti gubernur, bupati, dan walikota.

Dalam kaitan ini, Mulyana (2006:231) menyebutkan bahwa identitas etnik (etnisitas) terbentuk lewat interpretasi realitas fisik dan sosial, sebagai yang memiliki atribut-atribut etnik. Identitas etnik berkembang melalui internalisasi pengkhasandiri (self typication) oleh orang-orang lain yang dianggap penting (significant others) tentang siapa aku dan siapa orang lain berdasarkan latar belakang etnik mereka. Mead berpendapat bahwa konsepsi diri seseorang bersumber dari partisipasinya dalam budaya dimana ia dilahirkan atau yang ia terima. Budaya diperoleh individu lewat simbol-simbol dan simbol-simbol ini bermakna lewat eksperimentasi dan akhirnya famili- arity dengan berbagai situasi (Mulyana, 2006: 231).

Simbol dalam konteks ini adalah suatu rangsangan yang mengandung makna dan nilai yang dipelajari manusia dan respon manusia terhadap simbol adalah dalam pengertian makna alih-alih dalam pengertian stimulasi fisik dari alatalat indranya (Mulyana, 2006:77). Makna suatu simbol bukanlah pertama ciri-ciri fisiknya, namun apa yang dapat dilakukan orang mengenai simbol tersebut. Suatu simbol signifikan atau memiliki makna bila simbol itu membangkitkan pada individu yang menyampaikannya respon yang sama seperti yang juga akan muncul pada individu yang dituju.

Menurut Mead (dalam Mulyana, 2006) hanya apabila kita memiliki simbol-simbol yang bermakna, kita berkomunikasi dalam arti sesungguhnya. Komunikasi melibatkan tidak hanya proses verbal yang berupa kata, frasa atau kalimat yang diucapkan dan didengar tetapi juga proses nonverbal. Proses nonverbal meliputi isyarat, ekspresi wajah, artefak, pakaian, gerakan tubuh, sentuhan, dan paralinguistic. Dewey (Mulyana, 2006) secara tajam menyebut bahwa masyarakat eksis melalui komunikasi; perspektif yang sama, budaya yang sama, muncul melalui partisipasi dalam saluran komunikasi yang sama. Melalui partisipasi sosiallah perpektif bersama dalam kelompok diinternalisasikan dan berbagai pandangan muncul melalui kontak dan asosiasi yang berbeda. Rose (dalam Mulyana, 2006) juga berpendapat, dalam komunikasi dengan tanda alamiah, komunikator mengontrol perilaku pihak yang hadir, apakah dengan sengaja atau tidak, karena tubuh pihak kedua secara tetap merespon dengan spesifik terhadap impak rangsangan atas alat-alat indranya. Sementara dalam komunikasi dengan simbol signifikan sebaliknya, komunikator dapat mempengaruhi perilaku pihak yang hadir, namun ia tidak bisa mengendalikannya, karena simbol berkomunikasi dengan isi makna dan nilainya bagi pihak yang hadir.

Berdasarkan konsepsi simbol di atas dan kaitannya dengan identitas etnik atau etnisitas yang secara langsung berkaitan dengan simbolisasi ciriciri yang bersifat atau terikat oleh etnik tertentu, maka memilih tema simbolisasi etnik dalam ko- 
munikasi politik dan kampanye pemilukada menjadi sangat menarik. Pilihan Kabupaten Poso sebagai lokasi penelitian erat kaitannya dengan argumentasi di atas, terlebih jika mengingat daerah ini adalah daerah pasca konflik bernuansa etnis dan agama. Heterogenitas etnis yang mendiami Kabupaten Poso telah menyebabkan suburnya politik identitas. Mobilisasi dukungan digunakan dengan memanfaatkan komunikasi politik dengan pesan utama, putra daerah dan etnisitas lainnya. Ditambah lagi dengan disparitas agama yang dianut. Tim-tim sukses kandidat berlomba melobi dukungan, agama menjadi salah satu hal yang sangat menentukan. Bagaimana dan mengapa nilainilai religius yang transenden begitu merasuk dalam politik lokal manakala berbagai aturan formal tetap bersifat sekuler dan tidak satupun pemain kunci sangat agamis? (Klinken, 2007:129). Jawabannya berkaitan dengan kebutuhan calon menggalang dukungan politis.

Salah satu yang perlu dilihat dalam hal ini adalah aspek demografi kabupaten Poso. Prosentase etnik Kabupaten Poso berdasarkan analisis Suryadinata, dan kawan-kawan (2003) meski tidak sem-purna karena mencantumkan kategori etnik lainnya, menunjukkan bahwa Etnik lainnya sebagai prosentase paling besar yaitu 72,87 persen (yang diduga terdiri dari etnis Pamona, Napu, Bada, Mori, Tojo, Toraja, Timor dan lainnya) selebihnya etnis Gorontalo 8,44 persen, Bugis 6,33 persen, Jawa 3,89 persen, Bali 3,43 persen, Kaili 2,86 persen, Saluan 2,08 persen, Banggai 0,07 persen dan Buol 0,03 persen. Sementara prosentase penganut agama sebelum pemekaran adalah Islam sebesar 55,99 persen, Kristen 40,16 persen, Hindu 3,12 persen, Budha 0,04 persen dan agama lainnya 0,68 persen (Suryadinata, dan kawankawan 2003:177), sementara setelah pemekaran Kabupaten Tojo Una-una terpisah dari Kabupaten Poso pada tahun 2003 prosentase agama diperkirakan menjadi 58 persen Kristen, 36 persen Islam dan lima persen Hindu dan satu persen agama lainnya.

Sejarah Poso menunjukkan bahwa, dalam setiap pelaksanaan pemilukada baik sebelum reformasi maupun pasca reformasi selalu disertai dengan konflik politik yang nuansanya mengangkat etnisitas sebagai batas pembeda. Meski pada masa Orde Baru etnisitas dalam kepemimpinan
Poso dapat direduksi oleh kekuatan pusat, namun ketegangan antar tokoh atau calon bupati dan pendukungnya tidak bisa hilang. Terlebih setelah reformasi berlangsung, politik identitas etnik seolah menemukan lahan subur untuk menyemai. Berubah-ubahnya komposisi etnik dan agama pada aspek demografi penduduk Poso akibat konflik dan pemekaran wilayah menyebabkan dinamika politik di daerah ini juga sangat dinamis (Klinken, 2007).

Agaknya perilaku politik dan politik identitas etnik terutama dalam praktik komunikasi politik dan kampanye pada level nasional berbeda dengan konteks lokal. Hasil studi Aragon dalam (Nordholt, dan kawan-kawan, 2007) menyebutkan bahwa Bupati Poso mulai menerapkan politik identitas agama pada tahun 1998 karena termotivasi oleh kombinasi antara ideologi dan melindungi kekuasaan serta imbalan politis. Transisi ke otonomi dinilai terkait dengan kekerasan kolektif yang terjadi di Poso karena para pemimpin kabupaten berusaha memicu ketegangan agama untuk memobilisasi calon pemilih. Ketika proses mediasi konflik Poso berlangsung tahun 2001, dimana orang-orang Muslim dan Protestan lari dari wiayah mereka, para pemimpin Muslim melobi blok-blok etnis yang terpecah belah untuk menciptakan kabupaten-kabupaten baru bagi administrasi dan pembangunan. Politikus dari Muslim Bungku mengajukan gagasan Kabupaten Morowali untuk menyatukan etnis Bungku dan Mori, sebelum mangambil kendali Kabupaten Poso dari seorang pemimpin beretnis Tojo. Sebaliknya etnis Tojo mulai mengetengahkan usulan pembentukan Kabupaten Tojo Una-una sebagai sarana untuk meraih kembali sebuah pusat kekuasaan regional diwilayah etnis mereka sendiri.

Etnisitas menjadi aspek yang penting dalam hubungan politik. Pada dasarnya term ini muncul karena menyangkut gagasan tentang pembedaan, dikotomi antara kami dan mereka dan pembedaan atas klaim terhadap dasar, asal usul dan karakteristik budaya. Etnisitas adalah hasil dari proses hubungan, bukan karena proses isolasi. Jika tidak ada pembedaan antara orang dalam dan orang luar, tidak ada namanya etnisitas (Dwiyer, 1996 dalam Abdillah, 2002:15). Erikson (1993), menambahkan syarat kemunculan etnisitas adalah kelompok tersebut sedikitnya telah menjalin 
hubungan, kontak dengan kelompok etnis yang lain dan masing-masing menerima gagasan dan ide-ide perbedaan di antara mereka, baik secara cultural maupun politik.

Kemunculan politik etnis diawali oleh tumbuhnya kesadaran yang mengidentikkan mereka ke dalam suatu golongan atau kelompok etnis tertentu. Kesadaran ini kemudian memunculkan solidaritas kekelompokan dan kebangsaan. Politik etnis mengacu kepada politik "kelompok etnis" dan minoritas kecil sementara penafsiran kelompok etnis bisa mencakup bangsa etnis (ethnic nation). Pada wacana politik kontemporer nuansanya lebih sempit. Dalam konteks ini, biasanya kelompok etnis tidak memiliki teritori tertentu. Tujuan mereka pun berbeda dengan nasionalis klasik, mereka menghendaki "determinasi diri kebangsaan" dalam suatu wilayah bangsa. Akan tetapi, lebih pada penerimaan proteksi dan kemajuan bagi kelompok, khususnya bagi individu-individu dalam kelompok itu, dalam suatu negara yang sudah ada (Kellas, 1988 dalam Abdillah, 2002:18).

Etnisitas yang terbangun dalam relasi kekuasaan antar kelompok, merupakan sinyal keterpinggiran, sinyal tentang pusat dan pinggiran, dalam konteks sejarah yang selalu berubah. Di sini, pusat dan pinggiran dibentuk dalam representasi politik. Seperti argument Barth (1988:76), adalah penting untuk menjadikan sebuah aksioma bahwa apa yang dipresentasikan sebagai pinggiran tidaklah sepenuhnya pinggiran tetapi merupakan efek dari representasi itu sendiri. Simbolon menyatakan bahwa etnisitas merupakan hasil konstruksi proses sosial yang lazim disebut askripsi (ascription). Proses sosial menandai sekelompok masyarakat tertentu dengan sembarang tanda-apapun tandanya asal bisa dipakai untuk "menunjuk" (labeling), dan berlangsung dalam sebuah generasi yang dipengaruhi oleh kekuasaan (Incis, 2002:69).

Dalam konteks demokrasi lokal, terutama pada kontestasi pemilukada Horowitz dan Long (2006) berargumentasi bahwa demokrasi dalam masyarakat multi etnik memiliki beberapa tantangan utama karena sistem pemilu langsung memungkinkan salah satu atau beberapa dari etnis akan selalu menjadi pihak yang selalu terus menerus menang (permanent winners) dan pihak yang selalu terus menerus kalah (permanent losser). Persoalan akan kian memburuk ketika dalam lingkungan masyarakat tersebut hanya memiliki dua etnis saja yang bersaing. Namun persoalan pada umumnya akan lebih berkurang jika dalam lingkungan masyarakat tersebut terdiri dari beragam suku yang kecil dan mampu melakukan koalisi. Adanya koalisi-koalisi tersebut dalam arena pemilihan dapat memungkinkan masing-masing etnis tidak akan selamanya menjadi pihak yang selalu terus menerus menang dan pihak yang selalu terus menerus kalah.

Sementara itu Posner dan kawan-kawan (2005) berpendapat bahwa ada dua kecenderungan kalangan elit politik dan kandidat dalam menggunakan isu-isu etnis (playing ethnic card), para politisi dan kandidat biasanya menggunakan berbagai pola pendekatan terhadap etnisitas menjelang kontestasi. Para politisi dan kandidat biasanya menggunakan berbagai pola pendekatan terhadap etnisitas menjelang arena pemilihan. Target yang ingin didapat adalah adanya kelekatan dengan etnis yang menjadi obyeknya. Para politisi dan kandidat memainkan kartu etnis untuk mengamankan batas keunggulan yang dimilikinya dalam sebuah arena kompetisi baik ketika pemilu berlangsung maupun setelah pemilu.

Apa yang disampaikan oleh Posner tersebut nampaknya cukup penting dalam melihat kecenderungan dinamika etnisitas dalam berbagai peristiwa Pemilukada di beberapa daerah di Indonesia. Dari ratusan event Pemilukada yang pernah berlangsung di Indonesia, polarisasi etnis nampak mewarnai keseluruhan proses pelaksanaan Pemilukada. Tidak hanya itu, etnisitas juga berhimpit dengan beberapa faktor lainnya seperti agama dan suku dimana keseluruhan faktor tersebut berpengaruh terhadap geopolitik, ethnopolitik, dan demografik para konstituen dalam Pemilukada. Fenomena inilah yang seringkali menjadi alasan bagi sebagian kalangan elit yang menilai bahwa Pemilukada hanya akan membuka berbagai arena konflik etnis secara terbuka diberbagai daerah di Indonesia.

Berangkat dari berbagai argumentasi di atas penelitian ini hendak meretas permasalahan mengenai bagaimana simbol-simbol etnisitas yang selama ini oleh banyak ahli dianggap sebagai pemicu konflik di Kabupaten Poso diangkat se- 
bagai isu kampanye pada even pemilukada? Bagaimana pergeseran isu kampanye dan komunikasi politik selama pemilukada langsung diselenggarakan di Kabupaten Poso?

Dengan demikian rumusan tujuan penelitian ini adalah diharapkan teridentifikasinya simbol-simbol dan atribut etnik yang digunakan dalam politik perbedaan dan upaya mobilisasi dukungan politik dalam hal ini kampanye pemilukada dan menjelaskan pergeseran isu kampanye selama pemilukada dilaksanakan secara langsung di Kabupaten Poso.

\section{Metode Penelitian}

Penelitian ini adalah penelitian deskriptif kualitatif dengan pendekatan Interaksi simbolik yang berasumsi bahwa pada dasarnya kehidupan sosial adalah interaksi manusia dengan menggunakan simbol-simbol. Interaksi simbolik tertarik pada cara manusia menggunakan simbol-simbol yang merepresentasikan apa yang mereka maksudkan untuk berkomunikasi dengan sesamanya, dan juga pengaruh yang ditimbulkan penafsiran atas simbol-simbol ini terhadap perilaku pihakpihak yang terlibat dalam interaksi sosial. Secara ringkas metode interaksi simbolik di bangun dari premis-premis, berikut, Pertama, manusia merespon suatu situasi secara simbolik, artinya setiap orang merespon lingkungan, termasuk obyek fisik, perilaku manusia berdasarkan makna yang dikanung komponen-komponen lingkungan. Kedua, makna adalah produk interaksi sosial, karena itu makna tidak melekat pada obyek, melainkan dinegosiasikan melalui penggunaan bahasa. Ketiga, makna yang diinterpretasikan individu dapat berubah dari waktu ke waktu sejalan dengan perubahan situasi yang ditemukan dalam interaksi sosial (Mulyana, 2006). Teknik pengumpulan data dilakukan melalui wawancara mendalam dan studi dokumentasi. Wawancara dilakukan terhadap informan yang dipilih secara purposive dimana peneliti secara sengaja memilih orang-orang yang benar-benar dipandang memahami masalah yang diteliti. Adapun informan yang dipilih adalah sebagai berikut; (1) KPU; (2) Panwas Pemilukada; (3) Tokoh Adat Poso; (4) Tokoh agama dan tokoh masyarakat; (5) LSM; dan (6) Akademisi di Poso.
Wawancara mendalam (depth interview), dilakukan dengan menggunakan pedoman wawancara (guide interview) kepada informan untuk menggali pemikiran dan pengetahuannya yang berkaitan dengan konstruksi simbol-simbol identitas etnik yang dapat dijadikan sebagai pembeda (politik identitas etnik), isu kampanye atau sebagai sarana memobilisasi dukungan dalam Pemilukada. Dalam melakukan wawancara, peneliti menggunakan buku catatan, alat pemotret, dan tape recorder untuk merekam berbagai data dan informasi sepanjang tidak menggangu jalannya wawancara.

Untuk melengkapi data penelitian, peneliti menggunakan pula data yang bersumber dari dokumen-dokumen yang berkaitan dengan penelitian. Dokumen tersebut berupa arsip penyelenggara pemilukada, berita, dan artikel di surat kabar, foto-foto dan barang cetakan yang digunakan sebagai alat peraga kampanye yang menunjukkan adanya simbol-simbol dan atribut identitas etnik.

Data dan informasi yang telah dikumpulkan melalui studi pustaka, wawancara individual dianalisis dengan metode intepretasi makna data. Dalam proses analisis data yang pertama dilakukan adalah editing data dengan mengecek kebenaran hasil wawancara dan melakukan transkrip hasil wawancara, selanjutnya adalah melakukan pengelompokan data berdasarkan kebutuhan penelitian selanjutnya interpretasi makna data, dilakukan oleh peneliti bersama informan selama berlangsung wawancara di lapangan. Kemudian interpretasi makna data dilakukan lebih mendalam pada waktu menuliskan laporan dengan mengaitkan teori-teori yang relevan.

\section{Hasil Penelitian dan Pembahasan}

\section{Tanah Poso dan Lintasan Sejarah Politik Identitas}

Pada zaman penjajahan Belanda, Poso terkenal sebagai lahan misi Kristen paling sukses di Hindia Belanda (Aragon, 2000; Schrauwers, 2000; Kruyt, 1977). Para misionaris Protestan Belanda Kruyt dan Adriani tiba pada tahun 1892 dan mulai menggunakan pendekatan etnografis 
yang kontras dengan metode-metode kurang sensitive yang dipakai ditempat lain manapun yang sama sekali tidak terlepas dari proyek penjajahan. Keberhasilan misi mereka diperoleh setelah melalui kampanye yang berdarah-darah pada tahun 1905 ketika orang-orang pegunungan Pamona, Napu, Lore, dan Kulawi berbondongbondong memasuki agama para penguasa baru tersebut. Momentum traumatis tersebut adalah catatan pembentukan negara kolonial dengan identitas Kristen sebagai bagiannya di mana agenagen keberhasilan itu diwakili oleh guru-guru yang loyal, para tetua gereja dan para pegawai pemerintah yang dihasilkan (Klinken, 2007:122).

Poso secara etimologis dalam bahasa $\mathrm{Pa}$ mona berarti kekuatan. Sejumlah ahli sepakat bahwa Islam sebagai salah satu agama tradisi besar telah lebih awal masuk di wilayah pesisir Poso seiring dengan hadirnya para saudagar atau pedagang Bugis pada akhir abad XVI (Hasan dan kawan-kawan, 2001). Sementara agama Kristen (Protestan) kemudian menyusul dengan mengisi kekosongan pada daerah-daerah pedalaman Poso melalui para missionaris pemerintah kolonial Belanda yang direpresentasikan oleh kehadiran Kruyt di wilayah Poso pada tahun 1892 (Aragon, 1999).

Para neotradisionalis menganggap bahwa akar masalah Poso sebenarnya bersumber pada pergeseran makna struktur sosial masyarakat Poso dari nilai-nilai kultural ke nilai ekonomi (pasar). Menurut Schrauwers (1999) struktur sosial "Orang Poso" atau lebih tepat disebut sebagai To Pamona, pada masa lalu dikenal dengan istilah wa' angkabosenya. Struktur ini terbagi atas dua kelas, kabosenya adalah kelas masyarakat atas (borjuis atau pemilik modal) dan watua merepresentase kelas bawah (proletariat, buruh tani). Kabosenya meski sebagai kelas borjuis, mereka juga memposisikan diri sebagai pelindung bagi watua yang bekerja pada kabosenya.

Penjelasan tersebut mendukung penafsiran adanya hegemoni dan dominasi kelas yang berdampak pada marjinalisasi “orang asli" Poso. Salah satu penafsiran tersebut misalnya terlihat secara gamblang dalam uraian Aditjondro yang berargumen dengan merujuk pada pernyataan Raja Terakhir Poso bernama Wongko Lemba Talasa pada tanggal 11 Mei 1947, yang saya kutip kembali sebagai berikut;
Laut atau Teluk Tomini tidak ada pagarny, Hai kamu orang Arab, Hai kamu orang Tionghoa, Hai kamu orang Jawa, Hai kamu orang Manado, Hai kamu orang Gorontalo, Hai kamu orang Parigi, Hai kaти orang Kaili, Hai kamu orang Tojo, Hai kamu orang Ampana, Hai kamu orang Bungku, Hai kamu orang Bugis-orang Wotu, Hai kamu orang Makassar; Jika kamu tidak menaati perintahku kamu boleh pulang baik-baik ke kampung halamanmu karena Tana Poso tidak boleh dikotori dengan darah (Damanik 2003: 41).

Pernyataan Raja Poso di atas menjadi semakin menarik karena pertama, secara kultural menunjukkan fakta kemajemukan budaya orang Poso yang ditandai oleh eksistensi beragam komunitas etnik diPoso; kedua pernyataan tersebut juga secara eksplisit merupakan dukungan atas fakta bahwa komunitas orang-orang Arab, Tionghoa, Jawa, Manado, Gorontalo, Bugis, Makassar telah lama ada, atau paling tidak jauh sebelum program transmigrasi dengan gencar dilakukan oleh pemerintah Indonesia pada masa Orde Baru; ketiga, pernyataan tersebut sama sekali tidak menyinggung identitas keagamaan; dan yang terpenting, alih-alih menunjukkan seperioritas komunitas penguasa, pernyataan tersebut justru menggambarkan kedalaman pemahaman seorang pemimpin atas spirit masyarakat multikultural dan mengingatkan betapa pentingnya menjaga harmoni dan damai di Poso.

Salah satu aspek penting lain yang mempercepat heterogenitas Poso adalah migrasi. Migrasi suku bangsa pendatang ke Poso dalam masa Orde baru dan setelahnya adalah program transmigrasi. Transmigrasi sebagai proyek nasionalisme yang mengabsolutkan paradigma negara kesatuan yang membayangkan adanya sebuah komunitas tunggul dari rezim Orde Baru sesungguhnya dapat dikatakan telah gagal secara kultural, karena telah memunculkan sejumlah persoalan khususnya yang terkait dengan ketegangan-ketegangan hubungan antara komunitas asli Poso yang beragama Kristen dan kaum pendatang yang umumnya beragama Islam (Hoey, 2003:109).

Perubahan struktur demografi di Poso juga disebabkan oleh kelahiran otonomi daerah, melalui pembentukan kabupaten atau disebut 
pemekaran. Pembentukan Kabupaten Morowali terpisah dari Kabupaten Poso tahun 1999 merubah komposisi penganut agama Kristen yang sebelumnya mayoritas lalu menjadi 40 persen sementara Islam menjadi 57 persen. Angka segregasi itu lalu kembali berubah ketika Kabupaten Tojo Una-Una resmi di bentuk tahun 2003 terpisah dari Poso, di mana Kristen kembali mayoritas dengan penganut sekitar 58,52 persen (BPS, 2004). Pada periode tersebut konflik kekerasan yang terjadi juga menyebabkan adanya perpindahan penduduk melalui pengungsian dan motif lainnya.

Bacaan mengenai persaingan politik di Kabupaten Poso menunjukkan bahwa terdapat tendensi-tendensi etno-religius yang terhubung dengan persaingan-persaingan kekuasaan di daerah ini bahkan jauh sebelum kekerasan komunal mencuat ke permukaan di Poso. Hanya saja ketegangan-ketegangan dari domain etnis dan agama ini tidak berakhir dengan pertikaian terbuka karena adanya semacam konsensus tidak terbuka soal pembagian kekuasaan (power sharing) antara bupati dan wakil bupati berdasarkan etnoreligius, meski faktanya dari 16 bupati (empat pejabat bupati) sejak tahun 1948 - 2010, 11 diantaranya beragama Islam.

Walaupun agama adalah instrumen efektif dalam memobilisasi massa dan memperluas eskalasi konflik seperti yang terjadi di Poso, akar dan motif sesungguhnya dapat dikatakan bersifat politis dan koruptif (Norldholt:2003). Praktikpraktik korupsi yang secara luas terjadi di Poso dan di berbagai daerah di Indonesia pada umumnya mempunyai korelasi dialectic interplay dengan kekuasaan politik yang sama sekali tidak dimotivasi oleh referensi keagamaan apapun, baik secara struktural maupun kultural. Inilah yang menjadi alasan mengapa kasus Poso oleh banyak kalangan tidak dapat diberi label sebagai konflik antar-agama, namun bernuansa agama.

\section{Identitas Calon Bupati atau Wakil Bupati dan Partai Pengusung}

Untuk memetakan bagaimana isu etnis, agama, putera daerah dan pendatang bermain dalam kampanye dan komunikasi politik pada pemi- lukada Kabupaten Poso tahun 2010 maka berikut ini disajikan biografi singkat, afiliasi politik, dan partai pengusung para kandidat. Pemilukada Poso tahun 2010 diikuti oleh empat pasangan calon. Keempat pasangan ini memperlihatkan perpaduan yang unik dalam hal etnis dan agama yang menyertai identitas personal mereka di mata calon pemilih. Sebagaimana diketahui bahwa identitas yang melekat pada setiap individu akan menjadi penanda penting dalam kehidupan sosial. Wacana identitas berkembang seiring semakin bervariasi dan berkembangnya masyarakat.

Ada situasi yang sedikit berbeda dalam proses pemilihan umum kepala daerah di kabupaten Poso di tahun 2010. Perbedaan tersebut dapat dilihat dalam beberapa sisi yaitu; pertama, meskipun konfigurasi etno-religius masih dijadikan referensi oleh empat pasangan kandidat bupati dan wakil bupati yang akan bersaing memenangkan pemilihan umum kepala daerah Poso periode 2010-2015, namun calon bupati secara keseluruhan diisi oleh nama-nama yang berasal dari agama Kristen dan semua calon wakil bupati beragama Islam. Kedua, issu keamanan daerah yang pernah mengalami konflik komunal ini nampaknya masih dipandang strategis dalam pencitraan untuk memenangkan pemilihan umum kepala daerah. Pasangan dengan nomor urut satu adalah Hendrik Gary Lyanto dan Abdul Muthalib Rimi. Hendrik Lyanto dikenal oleh orang Poso dengan nama Aceo. Ia adalah putra Poso keturunan Tionghoa yang menjadi pengusaha sukses di daerah itu. Tapi, dia memindahkan basis bisnisnya di Jakarta dan Surabaya pasca konflik di daerah itu. Sebagai pengusaha, dia berharap bisa membangun pabrik pengolahan hasil pertanian di tanah Poso. Aceo dan pasangannya bertekad memulihkan ekonomi Poso yang terjerembab akibat kerusuhan bernuansa SARA beberapa tahun lalu dan memperbaiki kesejahteraan masyarakat yang jauh tertinggal dengan daerah lainnya.

Pendamping Aceo, Abdul Muthalib Rimi, Wakil Bupati Poso 2005-2010. Segudang pengalaman birokrasi menjadi nilai tambah pasangan Acea dan Abdul Muthalib Rimi yang ingin mengkombinasikan pengusaha-birokrat untuk memimpin Poso. Thalib, panggilan akrabnya, adalah pria kelahiran Mapane yang bergelar magister 
bidang hukum juga aktif di organisasi sosial keagamaan. Organisasi yang dipimpinnya, antara lain, Yayasan Ittihadul Ummah.

Pasangan calon dengan nomor urut dua; Sony Tandra dan Mulyadi, merupakan kolaborasi antara pengusaha dan politisi dengan anggota TNI. Sonny Tandra (50), yang dikenal di Poso dengan nama Aciong, adalah putera Poso keturunan Tionghoa yang memiliki latar belakang pengusaha dan kemudian menjadi politisi sejak enam tahun terakhir. Pengusaha mudaitu masih tercatat sebagai anggota DPRD Sulawesi Tengah dari Partai Patriot Indonesia. Ia dikenal sebagai lelaki yang santun dan berjiwa sosial. Dengan dukungan Partai Patriot, tempat menyalurkan aspirasi politik dan membawanya ke kursi DPRD Sulteng periode 2004-2009 dan 2009-2014. Mulyadi (58) adalah kolonel purnawirawan TNI. Ia pernah menjabat sebagai Komandan Kodim di Luwuk (19921997) dan Komandan Kompi B Poso (19731979). Karir legislatif pun pernah dilakoninya sebagai pimpinan DPRD Poso.

Pasangan dengan nomor urut tiga adalah Frans Wangu Sowolino dan Burhanuddin Andi Masse. Frans bukan wajah lama dalam Pilkada Poso. Putera asli Pomona ini menjadi "runnerup" pilkada 2005 yang saat itu dimenangkan Piet Inkiriwang. Ia adalah birokrat tulen. Pengalamannya di dunia birokrasi lengkap mulai dari camat sampai Ketua Bappeda Poso. Kegiatan sosial kemasyarakatan yang cukup luas juga menjadi nilai tambah bagi Frans dalam kompeitsi politik ini.

Sementara itu Burhanuddin Andi Masse berkarier di dunia pendidikan dan saat ini merupakan Ketua Asosiasi Perguruan Tinggi Swasta Indonesia (APTISI) Komisariat Provinsi Sulawesi Tengah periode 2009-2013. Ia juga aktif sebagai Pembantu Ketua I STMIK Bina Mulia Palu, dan Sekretaris Forum Rektor Sulawesi Tengah.

Kandidat dengan nomor urut empat adalah duet Piet Inkiriwang dan Syamsuri, kolaborasi antara pensiunan Polri dan birokrat. Piet Inkiriwang merupakan "incumbent", sekaligus Ketua Partai Demokrat, partai pemenang Pemilu 2009 di kabupaten yang terkenal dengan keindahan Danau Poso itu. Piet berkarier di kepolisian hingga mendapat pangkar komisaris besar po- lisi saat pensiun. Dunia legislatif pun pernah dijalani dengan menjadi anggota DPRD Sulawesi Utara. Ia lahir dari seorang ayah berdarah Minahasa dan ibu dari Sulewana di pinggiran danau Poso. Piet Inkiriwang sendiri yang mengakhiri masa jabatannya 31 Agustus 2010 yakin memenangkan pemilihan bersama pasangannya, Syamsuri, seorang birokrat berdarah Jawa yang terakhir kali menjabat sebagai Kepala Dinas PU Kabupaten Poso.

\section{Imagining Conflict dan Putera Daerah Sebagai Isu Kampanye}

Pilkada yang dilaksanakan secara langsung mensyaratkan popularitas seorang kandidat atau pasangan calon kepala daerah yang akan bertarung. Tingkat elektabilitas tinggi pasangan calon hanya dapat diperoleh melalui pengenalan atau sosialisasi yang sistematis dengan menggunakan metode komunikasi kontemporer yang sesuai dengan keadaan daerah di mana pilkada diselenggarakan. Karenanya salah satu hal penting yang menjadi perhatian tim kampanye pasangan calon kepala daerah adalah isu-isu yang akan dikomunikasikan dalam beragam medium komunikasi politik.

Penetapan isu strategis yang akan dikomunikasikan bagi setiap pasangan calon dalam pilkada langsung mesti dilakukan dengan cermat. Isu-isu penting tersebut harus di dasarkan pada karakteristik demografis, sosiografis dan psikologis. Pengembangan isu sebagai bagian dari proses kampanye memerlukan kejelian tim pemenangan pasangan calon agar tidak kontraproktif dengan tujuan atau sasaran yang ingin dicapai yaitu sebanyak-banyaknya pemilih untuk memenangkan pilkada. Bagi pasangan incumbent (petahana) isu strategis yang paling banyak dikembangkan adalah keberhasilan mereka dalam melaksanakan pembangunan di daerah baik menyangkut pembangunan fisik maupun nonfisik.

Di lain pihak, kandidat penantang yang berasal dari beragam latar belakang seringkali menggunakan isu kampanye yang menonjolkan keberhasilan mereka pada profesi atau jabatan sebelumnya. Tawaran kandidat penantang seringkali harus terdeferensiasi dengan kandidat petahana sekaligus harus menjadi tawaran solusi 
bagi hal yang belum berhasil dilaksanakan oleh petahana. Bahkan seringkali tim kampanye kandidat penantang menggunakan isu-isu yang menyerang dan menjelekkan kandidat petahana guna meraih simpati publik atau calon pemilih.

Pilkada Poso yang diikuti oleh empat pasang calon dengan beragam identitas etnik telah menyebabkan isu etnik menjadi jualan yang cukup menonjol. Dari sisi etnis. latar belakang keempat calon bupati cukup unik, Piet Ingkiriwang adalah seorang yang berdarah Minahasa dari pihak ayah dengan ibu beretnis Pamona dan lahir di Desa Sulewana sebuah desa di Kecamatan Pamona Utara yang ditengahnya dialiri Sungai Poso. Oleh karenanya meski ia kelahiran Pamona oleh lawan politiknya yang berasal dari etnis asli Pamona, Piet dianggap pendatang. Isu putera daerah ini banyak dikembangkan oleh satu-satunya kandidat beretnis asli pamona yaitu Frans Sowolino.

Sebagai kandidat petahana, Piet Ingkiriwang banyak mengkampanyekan keberhasilannya dalam menjaga keamanan dan memelihara perdamaian. Menurut para informan yang diwawancarai menyebutkan bahwa hampir disemua tempat pelaksanaan kampanye dan pada materi publikasi isu keamanan sangat ditonjolkan pasangan ini. Selain klaim keberhasilan pembangunan ekonomi, pendidikan, dan rehabilitasi Poso pasca konflik sosial. Isu ini memang cukup mengena, karena masyarakat Poso kebanyakan sudah menyadari bahwa konflik kekerasan dan saling bunuh antar agama dan etnis adalah hal siasia. Sehingga salah faktor penting yang harus dijaga untuk terus melaksanakan pembangunan Poso adalah faktor keamanan dan ketertiban.

Kutipan berita pada harian Media Alkhairat tanggal 27 Mei 2010 berikut ini juga menggambarkan bagaimana pasangan Piet-Samsuri mengeksplorasi isu keamanan sebagai isi kampanye.

"Pasangan Calon Bupati Piet InkiriwangSyamsuri yang mengusung isu kemanan sebagai keberhasilan dalam pemerintahannya mengaku dalam setiap kampanye terbuka di beberapa kecamatan. Mereka menyebutkan keamanan Poso yang terwujud selama pemerintahannya berkat kerja sama yang baik antara pemerintah pusat dan daerah serta dukungan seluruh masyarakat Poso. "Ini sebagai bukti, bahwa selama pemerintahan saya (Piet Inkiriwang) mampu membawa perubahan mendasar yang dibutuhkan masyarakat selama ini yaitu keamanan dan perdamaian. Saat ini masyarakat Poso sudah hidup tenang," kata Piet, Calon Bupati Petahana (incumbent) dalam beberapa kampanye terbuka ${ }^{1}$.

Bagi kandidat lain, isu keamanan ini dianggap sebagai klaim sepihak. Mereka menganggap bahwa terciptanya keamanan di Poso bukan andil dari kandidat petahana semata tetapi peran besar pemerintah pusat dan aparat keamanan dalam menjaga keamanan dan ketertiban di Poso. Selain itu mereka menganggap bahwa peran masyarakat yang telah menyadari pentingnya menjaga keamanan sehingga tidak lagi ada riak-riak yang mengganggu keamanan. Menanggapi hal tersebut tiga pasangan calon lainnya menganggap bahwa itu adalah klaim sepihak. Salah seorang Tim Kam-panye Pasangan Hendrik Gery LyantoThalib Rimi, Baharuddin Syafi'i di hadapan 12.000 massa yang memadati alun-alun Lapangan Sintuwu Maroso, Poso Kota pada kampanye tanggal 25 Mei 2010 menyoal salah satu kandidat bupati yang mengklaim situasi keamanan Poso yang kini makin membaik adalah kerja calon bupati petahana. Ia menyebutkan, keamanan tumbuh karena kesadaran masyarakat yang ingin hidup damai.

Sementara itu pada sejumlah kampanye yang dilaksanakan pasangan Sonny TandraMuljadi juga menolak jika damai di Poso adalah hasil kerja Piet Ingkiriwang, menurutnya situasi Poso yang sudah normal ini adalah kerja pemerintah pusat, aparat keamanan, dan masyarakat Poso sendiri. Pasangan Calon Bupati Frans Sowolino-Burhanuddin tak mau kalah menyerang isu keamanan ini. Juru Kampanye FransBurhan, Sonny Kapito menyebut, persoalan keamanan bukan tugas bupati tapi tugas aparat keamanan.

Tampaknya isu keamanan memang dianggap sebagai salah satu isu strategis yang harus dikedepankan oleh setiap pasangan kandidat bupati Poso. Para kandidat bupati manyadari betul bagaimana psikologi masyarakat Poso yang telah jenuh dan tidak lagi ingin berkonflik, saling menghujat dan saling bunuh karena provokasi 
yang kebanyakan melibatkan aktor-aktor dari luar Poso. Menurut Gogali (2010) menanggapi isu keamanan dan klaim pasangan Piet-Samsuri soal keamanan di Poso, bahwa dalam konteks masyarakat pasca konflik Poso, kata "aman" adalah kata ampuh yang mampu mengakomodir kebutuhan semua lapisan masyarakat. Mendengar kata ini semua orang hampir serentak seolah-olah memiliki deskripsi yang sama tentang unit kata tersebut yakni tidak adanya konflik, tidak adanya kerusuhan, tidak ada bom, tidak ada lagi penembakan, dan pembunuhan misterius, semua orang dapat beraktivitas ke kebun, sekolah atau kantor. Tidak lagi menjadi penting apakah aman berarti damai, apakah aman berarti juga ada keadilan, kesejahteraan. Kata ini seolah menjadi kata magis bagi masyarakat yang trauma dengan kata sebaliknya; konflik. Masyarakat diseret, dipaksa, diarahkan untuk memiliki makna yang sama seperti yang ditentukan oleh penguasa.

Penggunaan kata ini menjadi relevan, bukan karena kebenarannya namun karena konteks yang dibicarakannya. Pertama, dibicarakan dalam konteks masyarakat pasca konflik yang jelas lelah, enggan berada dalam situasi konflik, bahkan jika sekedar membicarakannya. Konteks ini membawa alur hidup masyarakat digiring pada kebutuhan yang penting aman, terserah saja politik kalian di atas sana yang penting aman. Lalu, masyarakat diyakinkan bahkan setelah konflik kekerasan telah berakhir, aman adalah kebutuhan mereka, hanya aman, bukan peningkatan ekonomi, apalagi mendapatkan keadilan dan mencapai kesejahteraan.

Kedua, kata aman tidak saja secara efektif menjadi kata yang membuat masyarakat mengangguk setuju, tetapi diam-diam pada saat yang bersamaan menyusup, menelisik, menjadi kata yang meneror. Alih-alih menjadi kata yang menjamin kebutuhan kondisi pasca konflik, kata ini menjadi senjata untuk menakut-nakuti masyarakat. Jika masyarakat tidak memperhitungkan rasa aman sebagai hal penting yang paling mendasari aktivitas mereka maka mereka terancam kehilangan jaminan kehidupan "normal" sekarang, bahkan bukan tidak mungkin kehilangan kehidupan.

Ketiga, konflik kekerasan sepanjang 12 tahun di-retrive-(dipanggil kembali) dengan vul- gar cenderung kasar dengan menempatkan pengalaman mengungsi, lari di hutan, dan perbukitan (kata babungkus). Bertolak belakang dengan usaha-usaha perdamaian yang dikembangkan oleh aktivis perdamaian maupun yang diusahakan masyarakat, trauma dan rasa curiga dijaga, dipelihara bahkan dihembuskan kembali untuk memperingatkan masyarakat. Pengalaman konflik yang bahkan tidak dirasakan langsung oleh Ingkiriwang, digunakan, dimanfaatkan untuk menegaskan kepentingan rasa aman masyarakat.

\section{Simbol-simbol Etnis dan Agama dalam Kampanye dan Komunikasi Politik}

Dalam dunia politik, terutama pada negara yang demokrasinya belum matang, patronase politik masih menjadi bagian penting dalam menganalisis kemenangan seseorang dalam kontestasi politik. Dalam konteks pilkada Poso, persoalan patronase politik kelihatannya tidak terlalu banyak melibatkan aktor-aktor politik lokal yang berasal dari struktur partai resmi yang mengusung pasangan calon bupati-wakil bupati. Demikian halnya dengan tokoh politik nasional, lihat saja pasangan calon bupati Sonny Tandra yang diusung oleh Partai Patriot dengan beberapa partai lainnya.

Dalam hal keterlibatan simbol-simbol keagamaan tampaknya tidak terlalu signifikan dalam meraup perolehan suara calon bupati dan wakil bupati. Namun dalam hal paket calon yang diajukan masih sangat berpengaruh, ini terkait dengan proporsi jumlah penganut agama di Kabupaten Poso. Keterlibatan tokoh-tokoh kharismatik GKST (Gereja Kristen Sulawesi Tengah) misalnya tidak melibatkan simbol-simbol secara langsung tetapi mereka terlibat secara personal. Pendeta Damanik, yang secara terang-terangan mendukung pasangan Sonny-Mulyadi tidak membawa serta simbol-simbol GKST dalam kampanye. Beberapa tokoh GKST lainnya mendukung pasangan berbeda sehingga dukungan juga terpecah.

Di pihak Islam ketua FKUI (Forum Komunikasi Umat Islam) salah satu organisasi penting pada masa konflik dan proses damai di Poso juga tidak terlibat langsung tetapi hanya melibatkan tokoh-tokoh kharismatiknya. Ustad Gani Israil 
yang kini menjadi anggota DPRD dari Partai Demokrat jelas mendukung Piet Ingkiriwang ketua DPD Partai Demokrat di Poso terlepas posisinya sebagai Ketua FKUI, tokoh lainnya tersebar ke calon pasangan lain.

Menarik menyimak kutipan tulisan dalam blog Lian Gogali berikut ini untuk menggambarkan bagaimana peran tokoh-tokoh agama dalam Pilkada Poso tahun 2010.

"Salah seorang eks kombatan yang mengklaim memiliki basis massa (muslim) di wilayah Poso bergabung dengan eks kombatan lainnya yang memiliki basis massa (kristen) di wilayah Tentena menjadi satu tim sukses. Ratusan hingga ribuan massa dengan segala atribut, termasuk simbol keagamaan, naik mobil, sepeda motor dan truk dari Poso ke Tentena dan sebaliknya. Ratusan orang yang selama lebih dari sepuluh tahun pasca konflik kekerasan tidak pernah (baca:berani) bepergian ke wilayah Poso atau Tentena, melintasi wilayah tersebut dengan perasaan aman".

Dengan perpektif berbeda, Lian Gogali melihat kampanye pemilukada sebagai ajang bagi bersatunya dua komunitas yang dulunya berkonflik berkat keterlibatan tokoh-tokoh agama dalam satu tim kampanye. Jelas di sini bahwa patronase politik tokoh mendapatkan penegasannya, tetapi karena cairnya bentuk dukungan tokoh dari kelompok besar organisasi keagamaan menyebabkan calon pemilih juga memilih berdasarkan tokoh yang disegani. Lian menilai bahwa fenomena ini menegaskan adanya dekonstruksi masa lalu (konflik) sehingga meminggirkan halhal yang hegemonik di masyarakat bahwa konflik yang terjadi di masa lalu itu adalah konflik agama. Alih-alih meletakkan masa kampanye sebagai bagian dari ritual politik dalam Pilkada, masyarakat Poso menempatkannya sebagai bagian penting proses re-interpretasi yang menjadikan mereka melintasi batas identitas hingga akhirnya melakukan dekonstruksi konflik Poso.

Re-interpretasi bagi masyarakat diterjemahkan dengan tenggelamnya identitas agama dan suku sebagai pertimbangan utama pemilih dalam memilih. Hasil dari proses re-interpretasi tersebut telah melahirkan pengakuan tentang kepentingan bersama pada kekinian dan masa depan Poso. Buktipengakuan inidiekspresikan pada bergabungnya masyarakat lintas agama dan suku dalam kerumunan massa kampanye tanpa gesekan dan sentimen tertentu. Bahkan, diluar berbagai kepentingan ekonominya, antar eks kombatan dari kedua kelompok keagamaan bergabung dan memperjuangkan kandidatnya. Pengakuan ini membawa diri dan komunitas pada titik diam sejenak, menyimak ulang, memaknai masa lalu sebagai sesama manusia.

Jika kita kembali mencermati kombinasi dari pasangan kandidat calon bupati dan wakil bupati Poso di atas, di mana keempat calon bupati beragama Kristen sementara keempat calon wakil bupati beragama Islam, memang menunjukkan kombinasi yang tidak memungkinkan untuk menonjolkan persoalan agama dalam merebut pemilih. Hal ini berbeda dengan pilkada yang berlangsung sebelumnya, tahun 2005 di mana pilkada calon bupati dan wakil bupati sarat dengan isu agama yang akhirnya menyebabkan konflik terbuka. Sekedar membandingkan, pada pamilukada tahun 2005 yang diikuti lima pasangan calon dengan beragam identitas agama dan etnis.

Selain pasangan calon yang berasal dari beragam latar belakang, dukungan partai politik juga menunjukkan kecenderungan dukungan partai berbasis agama pada dua pasangan calon yang saat itu dianggap kuat untuk memenangkan pilkada. Pasangan Piet-Muthalib yang di dukung oleh Partai Damai Sejahtera yang berbasis Kristen dan pasangan Muin-Osbert yang didukung oleh dua partai berbasis Islam, yaitu Partai Amanat Nasional dan Partai Bintang Reformasi. Data hasil perhitungan suara pada pemilu 2005 berdasarkan kecamatan menunjukkan bahwa dari 12 kecamatan, 10 kecamatan dimenangkan oleh pasangan Piet-Muthalib. Di mana kesepuluh kecamatan tersebut dihuni oleh mayoritas penduduk beragama Kristen dengan rata-rata perolehan suara mencapai 48,9 persen. Dari 10 kecamatan tersebut, delapan diantaranya ditempati calon bupati berlatarbelakang Kristen lainnya, Frans-Kahar pada perolehan suara di nomor dua dengan rata-rata perolehan suara di kecamatan mayoritas Kristen sebesar 23,4 persen. Semantara dua kecamatan yang penduduknya mayoritas Islam, yaitu Poso Kota dan Poso Pesisir dimenang-kan oleh calon bupati berlatarbelakang Islam, Muin-Osbert. Hanya saja kemenangan pada dua kecamatan 
tersebut hanya 29,4 persen sehingga tidak berarti apa-apa jika dilihat secara keseluruhan.

Data tersebut menegaskan bahwa pada pemilu tahun 2005, faktor sentimen keagamaan masih sangat kuat dalam menentukan pilihan calon pemilih. Keadaan tersebut telah bergeser pada pemilu tahun 2010, isunya menjadi lebih bersifat rasional. Hal itu juga ditegaskan dari hasil wawancara dengan Iskandar Lamuka, Ketua KPU Kabupaten Poso;

"Iya, kalau tahun 2005 memang benar, isu itu sangat kental bahwa agama itu di nomor satukan dalam meraih suara dan itu masih sangat berpengaruh. Terbukti ketika ditelusuri Piet itu diusulkan oleh PDS tahun 2005. Ketika seorang kandidat atau pasangan kandidat yang diusung partai bernuansa agama pada saat itu PDS, Partai DEMOKRAT, PKS itu secara otomatis, karena pada saat itu situasi di Poso masih dalam suasana konflik sehingga ketika ada partai yang mengusung dari partai basis agama secara otomatis berpengaruh".

Jika isu agama nampaknya tidak lagi menjadi kunci kemenangan pemilukada 2010, faktor kedekatan etnis masih cukup bisa diperhitungkan meski dengan kadar yang relatif kecil. Hal ini dapat kita lihat pada perolehan suara kandidat berdasarkan kecamatan, yang menunjukkan adanya kecenderungan kemenangan pasangan tertentu pada daerah yang basis etnis di mana salah satu pasangan calon berasal. Misalnya kemenangan Pasangan Hendrik-Muthalib di Kecamatan Poso Kota Utara dan Poso Kota ditengarai karena faktor ketokohan Muthalib yang kebetulan beretnis Bugis, etnis yang mayoritas di kedua kecamatan tersebut. Demikian halnya dengan posisi nomor dua yang diperoleh pasangan Sonny-Mulyadi di Kecamatam Poso Kota di-tengarai karena faktor kesamaan etnis Mulyadi dengan etnis terbanyak kedua di kecamatan ini, yaitu Jawa. Selain dari data perhitungan tersebut, pada saat kampanye terdapat banyak paguyuban berbasis etnis yang mengambil bagian dalam pawai dengan spandukspanduk pernyataan dukungan atas calon tertentu. Menurut keterangan informan, Iskandar Lamuka, sepanjang pengamatannya paguyuban-paguyuban itu cukup berpengaruh dalam mengumpulkan massa pada saat kampanye. Ia mencontohkan bahwa terdapat keterlibatan Laskar Bugis Ma- kassar, Kesatuan Masyarakat Gorontalo dan Paguyuban Masyarakat Jawa. Pada saat penelitian, tim peneliti masih sempat menemukan spanduk yang tertempel di sebuah kios di jalan poros Poso-Moengko yang meski sudah agak usang tapi masih jelas tertulis "Posko Laskar Bugis-Makassar".

Permainan simbol-simbol etnis dan agama itu tidak lepas dari harapan memperoleh dukungan pada basis massa yang spesifik. Konstruksi simbol-simbol tersebut dengan sengaja dihadirkan tim kampanye untuk menggugah para calon pemilih dengan bentuk proximitas dan kebanggaan etnis. Ini tentu saja tidak lepas dari masih kuatnya bentuk politik patronase dan karakter komunalisme pada masyarakat pedesaan di Poso.

Bentuk lain yang dapat ditemukan dalam penelitian ini adalah penggunaan atribut-atribut etnis. Penggunaan pakaian adat misalnya memberikan ciri khusus yang dapat diidentifikasi sebagai bagian dari komunitas tertentu. Penggunaan pakaian adat sebagai simbol identitas etnik seseorang dalam pilkada menunjukkan adanya upaya untuk menggiring komunitas pada pilihan seragam dengan upaya menonjolkan simbolsimbol bersama. Para kandidat berusaha menunjukkan identitas tersebut jika berada pada komunitas etniknya. Kandidat calon wakil bupati, Samsuri misalnya mengenakan blangkon sebagai simbol lelaki Jawa. Demikian halnya dengan kandidat bupati Frans Sowolino yang senantiasa mengenakan pakaian adat Pamona untuk mempertegas identitasnya sebagai orang asli Pamona sebagaimana getol ia kampanyekan.

Terkait dengan pakaian adat, bahasa daerah juga memiliki peran yang cukup penting untuk meyakinkan warga masyarakat bahwa seorang kandidat itu memiliki ikatan primordial yang kuat dengan mereka. Penggunaan bahasa daerah pada wilayah yang secara mayoritas menggunakan bahasa daerah tersebut tentu memberikan citra tersendiri bagi seorang calon (Lampe, 2010). Menyapa warga Kelurahan Gebang Rejo di Kota Poso dengan bahasa Jawa misalnya, diyakini akan memberikan citra positif yang lalu bisa dimanfaatkan untuk mendekatkan hubungan emosional warga dengan sang kandidat. Konteks lokalitas lain di daerah Poso yang begitu heterogen dengan pola pemukiman yang terkotak-kotak kebanyak- 
an berdasarkan agama yang dianut dan juga berdasarkan etnis telah memberi ruang yang sangat terbuka bagi pemanfaatan beragam identitas etnik tersebut sebagai jalan memperoleh dukungan politik.

Bermainnya simbol-simbol tersebut dalam tataran politik lokal tidak dapat dihindari karena masih kuatnya isu etnisitas dalam setiap kontestasi politik. Bahkan jika kita merujuk pada pemekaran wilayah, sebagai kebijakan pelaksanaan otonomi daerah menunjukkan bahwa kesamaan latar belakang sejarah dan kesamaan etnis menjadi salah satu alasan utama dimekarkannya sebuah daerah otonom baru. Karenanya apa yang disampaikan oleh Horowitz dan Long (2006) menjadi tegas bahwa persoalan etnisitas dalam arena kontestasi ini dapat direduksi jika para kandidat dan politisi yang terpilih dalam arena pemilihan mampu memberikan sejumlah kebijakan publik yang memperhatikan dan mengakomodasi kalangan etnik minoritas yang kalah dalam kontestasi. Begitupun dengan pendapat Posner dan kawankawan (2007) bahwa ada dua kecenderungan kalangan elit politik dan kandidat dalam menggunakan isu-isu etnik (playing ethnic card), para politisi dan kandidat biasanya menggunakan berbagai pola pendekatan terhadap etnisitas menjelang pilkada.

Peta persaingan keempat kandidat jika dilihat dari sudut wilayah dan keterikatannya dengan wilayah tersebut nampaknya terdapat beberapa hal yang patut dicermati. Kekalahan telak Frans Sowolino di basis etnik Pamona di wilayah yang mengitari Danau Poso yang terbagi dalam lima kecamatan yang memperebutkan 43.888 suara atau 37,7 persen suara sah menjadi cukup menarik. Praktis pasangan Frans-Burhan hanya menang di Kecamatan Pamona Tenggara dengan selisih suara yang sangat tipis dengan pasangan Piet-Samsuri yang berada di Posisi kedua. Kecamatan lain yang tidak dimenangkan oleh bupati petahana dan hanya berada di posisi kedua adalah Kecamatan Pamona Barat, di wilayah ini SonnyMulyadi menang dengan cukup signifikan.

Frans Wangu Sowolino yang asli Pamona ternyata tidak mampu berbuat banyak menghadapi petahana. Isu putera daerah asli ternyata tidak cukup mampu merebut hati masyarakat etnik Pamona dan Mori di daerah tersebut memilihnya dalam pilkada. Padahal dengan modal politik yang demikian besar, semestinya ia tidak mengalami kekalahan telak di daerah tempat ia berkiprah setelah mengundurkan diri dari jabatan birokrasi di Pemda Poso. Frans sebagaimana diketahui sebelumnya adalah calon bupati periode 20052010 yang kalah dari pasangan Piet IngkiriwangAbd. Muthalib Rimi dan berada di posisi kedua perolehan suara.

Jika kita melihatnya dari sudut etnis dan agama maka terdapat aspek kedekatan pada masing-masing calon. Pamona Utara yang memiliki jumlah pemilih paling besar, secara tradisional menjadi basis bagi dua pasangan calon yang berasal dari daerah ini yaitu Piet Ingkiriwang dan Frans Sowolino. Meski berasal dari daerah yang sama, Frans mengklaim sebagai putera daerah asli karena nenek moyangnya memang asli Pamona sementara Piet adalah putera kelahiran Sulewana yang "hanya" ber-ibu orang Pamona. Meski demikian nampaknya, para pemilih di daerah Pamona tidak lagi tertarik dengan isu putera daerah yang gencar dikampanyekan oleh pasangan Frans-Burhanuddin.

Demikian halnya jika melihat kedekatan emosional Frans dengan masyarakat sub etnik Lore yang mendiami enam kecamatan. Frans yang beristerikan orang asli Lore juga mengalami kekalahan telak di enam kecamatan tersebut. Tapi kedekatan hubungan emosional, juga bukan sebuah kebetulan jika Sonny Tandra mampu menang di daerah Pamona Barat yang merupakan daerah asal isterinya. Faktor keamanan yang oleh beberapa tokoh politik di Poso dianggap sebagai isu utama yang menjadi kunci kemenangan petahana bisa saja gugur jika melihat kecenderungan kemenangan mutlak Piet-Samsuri di sekitar wilayah sekitar Danau Poso dan menyisakan masing-masing kemenangan bagi pasangan SonnyMulyadi dan Frans-Burhan.

\section{Simpulan}

Pemilukada langsung menjadi ajang terjadinya kontestasi dan rivalitas secara terbuka para tokoh politik Poso dalam meraih dukungan politik untuk mencapai kekuasaan, yang representasinya secara nyata dapat ditelusuri pada isu-isu komunikasi politik dan kampanye para kandidat. Pemilukada langsung telah menguji 
tesis-tesis tentang etnisitas dan politik identitas yang selama ini diyakini bersumbangsih besar terhadap terjadinya konflik kekerasan berkepanjangan. Situasi tersebut nyatanya mendapatkan pembuktian ketika pemilukada langsung dilaksanakan pertama kalinya tahun 2005. Konflik kekerasan mewarnai pelaksanaan pemilukada tersebut. Demonstrasi, teror, pembakaran, dan bentrok antar pendukung pasangan calon berlangsung kala itu. Pemilukada tahun 2005 menegaskan politik identitas, baik berdasarkan etnis dan agama sangat kental di tanah Poso sebagai isu utama.

Sementara itu pemilukada tahun 2010, menunjukkan bahwa ikatan primordial dan isu identitas masih banyak ditemukan dalam serangkaian proses pelaksanaan pemilukada, terutama pada saat kampanye. Hal ini dapat kita lihat misalnya dengan penggunaan simbol-simbol etnis, simbol-simbol keagamaan dalam berbagai kesempatan, meski tidak melibatkan secara langsung aspek kelembagaan agama. Bukti lainnya adalah kemenangan pasangan calon tertentu di wilayah yang mayoritas memiliki kesamaan identitas baik etnik, asal daerah dan agama misalnya, pasangan Gary Lyanto-Abdul Muthalib Rimi menang di Kecamatan Poso Kota Utara dan Poso Kota yang banyak dihuni masyarakat etnis Bugis (Muthalib adalah tokoh masyarakat yang beretnis Bugis) atau perolehan suara signifikan pasangan Frans-Burhan di daerah Pamona, tempat asal Frans Sowolino.

Dari hasil penelitian dapat dijelaskan pula bahwa Pemilukada Poso tahun 2010 memperlihatkan adanya pergeseran yang signifikan dalam hal penggunaan identitas etnik dalam komunikasi politik dan kampanye memperebutkan suara calon pemilih. Menguatnya wacana tentang pentingnya rasa aman dan kesejahteraan masyarakat terutama terkait dengan kesehatan, pendidikan, dan pengentasan kemiskinan sebagai isu utama dalam komunikasi politik dan kampanye para kandidat dibandingkan dengan isu-isu etnisitas yang selama ini ditengarai berperan besar dalam setiap konflik di Poso. Kejenuhan dan frustasi masyarakat Poso terhadap konflik kekerasan yang berkepanjangan telah merubah lanskap politik identitas yang selama ini mapan dalam politik Poso. Tampaknya terjadi re-interpretasi dalam masyarakat Poso ketika menterjemahkan isu kampanye yang menjual identitas agama dan suku sebagai pertimbangan utama dalam memilih pasangan calon. Isu-isu keamanan dan kesejahteraan menenggelamkan berbagai identitas etnik yang dimainkan dalam kampanye. Tenggelamnya identitas sebagai isu utama (berbanding terbalik dengan isu awal konflik Poso) menunjukkan "kesepakatan" alami (yang diam namun memiliki dampak mendalam) tentang adanya politisasi isu agama dalam konflik kekerasan yang mereka alami. Hasil dari proses re-interpretasi tersebut telah melahirkan pengakuan tentang kepentingan bersama pada kekinian dan masa depan Poso. Bukti pengakuan ini diekspresikan pada bergabungnya masyarakat lintas agama dan suku dalam kerumunan massa kampanye tanpa gesekan dan sentimen tertentu.

\section{Ucapan Terima Kasih}

Penulis menyampaikan terima kasih yang sebesar-besarnya kepada para informan, terkhusus kepada Ketua KPU Poso dan Pembantu Rektor III Unsimar Poso yang telah bersedia membantu peneliti selama di Poso. Kepada DP2M-Dikti atas biaya penelitian yang menjadi dasar penulisan artikelini.

\section{Daftar Pustaka}

Abdillah S, Ubed, 2002, Politik Identitas Etnis; Pergulatan Tanda Tanpa Identitas, Magelang, Indonesiatera.

Aragon, L.V., 2000, The Colonial Introduction of Religion and Language as Ethnicity in Sulawesi, Indonesia, University of Hawai Press, Honolulu.

Barth, Fredrik, 1988, Kelompok Etnik dan Batasannya, Terjemahan nining I Susilo, UIP, Jakarta.

Damanik, Rinaldy, 2003, Tragedi Kemanusiaan Poso: Menggapai Surya Pagi Melalui Kegelapan Malam, PBHI \& LPS-HAM Sulteng, Jakarta \& Palu.

Eriksen, Thomas Hilland, 1993, Ethnicity and Nationalism (anthropological perspective) Pluto Press, London.

Hasan, dkk., 2004, Budaya dan Adat Istiadat Poso, Pustaka Timur, Yogyakarta. 
Hoey, Brian A., 2003, "Nationalism In Indonesia: Building Imagined And Intentional Communities Through Transmigration".

Horowitz, Donald L., 1981, Ethnic Group in Conflict, University of California Press, California.

Horowitz, Jeremy dan James D. Long, 2006, Democratic Survival in Multi-etnik Countries, Working Paper, Department of Political Science, University of California, California.

Ilyas, 2010, Identitas Etnik dalam Komunikasi Politik, Jurnal Ilmu Komunikasi FISIP UPN Veteran Jogjakarta Volume 8 Nomor 3. September - Desember 2010.

INCIS, 2002, Hubungan Antar Etnik dan Masalah Kebangsaan di Jakarta, Laporan Penelitian INCIS Jakarta.

Isaacs, Harold R., 1993, Pemujaan terhadap Kelompok Etnis (Identitas Kelompok dan Perubahan Politik), Terjemahan
Canisyius Maran, Yayasan Obor Indonesia, Jakarta.

Klinken, Gerry Van. 2007. Perang Kota Kecil; Kekerasan Komunal dan Demokratisasi di Indonesia, Buku Obor-KITLV, Jakarta.

Kruyt, J., 1977, Kabar Keselamatan di Poso, BPK Gunung Mulia, Jakarta.

Lingkaran Survey Indonesia, Faktor Etnis dalam Pemilukada: Politik Etnisitas dan Politik Identitas dalam Politik, Kajian Bulanan, Edisi 09 Januari 2008.

Nordholt, Henk Schulte, Klinken, Gerry Van dan Ireen Karang-Hoogenboom (editor). 2007, Politik Lokal Indonesia, KITLF - YOI, Jakarta.

Posner, Daniel N., 2005, Institution and Ethnic Politics in Africa, Cambridge University Press, New York.

Schrauwers, 2000, Colonial Reformation " in the Highlands of Central Sulawesi, Indonesia, 1892-1995, University of Toronto Press, Toronto Buffalo London. 